\title{
Hans Delbrück
}

\section{GESCHICHTE DER KRIEGSKUNST}

Teil 2

Die Germanen

Vom Kampf der Römer und Germanen bis zum Übergang ins Mittelalter

Mit einer Einleitung von

Hans Kuhn und Dietrich Hoffmann 
